\title{
A Study of Drug Information Service for Prescription Containing Antibiotic and its Sale without Prescription in Tangerang City Indonesia
}

\author{
Ambar Listyorini ${ }^{1}$, Yardi Saibi ${ }^{2 *}$, Nurmeilis ${ }^{3}$ \\ (ambarlistyorini123@gmail.com¹,yardi@uinjkt.ac.id ${ }^{2}$, nurmeilis@uinjkt.ac.id ${ }^{3}$ ) \\ *corresponding author \\ 1,2,3 Pharmacy Study Program, Faculty of Health Sciences, UIN Syarif Hidayatullah Jakarta, \\ Ciputat, 15419, Indonesia
}

\begin{abstract}
Antibiotic resistance can be caused due to its improper use. This study aimed to investigate the profile of information provided by pharmacy staff in Tangerang City to patients with prescriptions containing antibiotics and the actions taken by them on requests for antibiotics without a prescription. This was a crosssectional study. Data were collected from pharmacy through the simulation patient method. Ethical clearance was obtained from the Ethics Committee of the Faculty of Medicine, University of Indonesia. The results showed that of the 55 pharmacies visited by patients, $98.18 \%$ of pharmacy staff who dispensed drugs to patients were non-pharmacists. The most information items provided to patients were the frequency of drug use. As many as $89.09 \%$ of pharmacy staff gave additional antibiotics asked by patients without prescription. Pharmacy staff services for patient taking antibiotic drugs in Tangerang City need to be reevaluated so that they are in accordance with regulations.
\end{abstract}

Keywords: simulated patients, antibiotics without prescription, drug information service, Tangerang city

\section{Introduction}

Drug information service is one of the pharmacy staff responsibility that have been regulated in the Minister of Health regulation number 73 of 2016 concerning pharmaceutical service standards in pharmacy. Pharmaceutical service standards in pharmacy include two main responsibilities, first the management of pharmaceutical preparations, medical devices, and consumable medical materials and the second is clinical pharmacy services. Clinical pharmacy services include prescription assessment, dispensing, drug information service, counseling, home pharmacy care, monitoring drug therapy, monitoring drug side effects [1].

Drug information services should be carried out due to it can increase patient knowledge about the drugs they use so that they have an impact on patient adherence. Several previous studies reported the low quality of drug information services received by patients from pharmacy staff. In a study conducted in Ngajuk Regency, East Java, Indonesia showed that the drug information service carried out by pharmacists was $27.8 \%$ and the rest was carried out by non-pharmacist pharmacists $(72.2 \%)$, but for the quality of drug information services performed 
by pharmacists are better than non-pharmacists which was $22.80 \%$ compared to $3.3 \%$ respectively [2]. Another study conducted in Bandung Regency, West Java, showed that drug information services quality carried out in Bandung Regency West Java was 24.91\% [3].

Another cause that has the potential risk to the development of widespread resistance to antibiotic is the use of antibiotics without a doctor's prescription. The use of antibiotics without a doctor's prescription is still widely practiced. According to World Health Organization (WHO) in 2015, dispensing antibiotics without a prescription had a percentage of $64 \%$ for the Southeast Asia region [4]. Several studies have shown that the dispensing of antibiotics without prescription was still found in the community, including in Indonesia. A study conducted in Kendari City showed that $87.45 \%$ of patients had the habit of using antibiotics without a previous doctor's prescription and most of the patients received antibiotics at a pharmacy with a percentage of $94.07 \%$ [5]. Research conducted in Nganjuk District showed 94\% of pharmacies could provide antibiotics even without a doctor's prescription [2]. Research in Bandung district shows that $82.66 \%$ of pharmacies in Bandung Regency provide antibiotics without using a doctor's prescription [3]. The antibiotics dispensing of without a doctor's prescription occurred not only in developing countries, but also in developed countries. For example, in European countries such as Romania and Lithuania, it was also found a high prevalence of self-medication with antibiotics [6]. In Spain 108 pharmacies dispensed antibiotics, only $52.8 \%$ of them explained that they could not administer antibiotics freely to avoid antibiotic resistance, and the highest use of antibiotics for urinary tract infections was 79.7\% [7]. Research in Saudi Arabia showed that $77.6 \%$ of antibiotics were administered without a doctor's prescription [8]. With the background of the conditions above, this study aimed to find the quality of drug information services for prescriptions containing antibiotics; the drug information provided by pharmacy staff; the profile of staff who gave the drug information; and to describe the dispensing of antibiotic without prescription in pharmacies in the city of Tangerang, Banten, Indonesia. This kind of study had never been conducted in the city.

\section{Method}

This was a cross-sectional study with a survey method that was carried out without intervening on the research subjects. The data collection was carried out by participatory observation, namely the researcher who was also an observer acting as a patient visiting the selected pharmacy with a prescription containing antibiotics during 2019. The observation was performed in the day. Immediately after receiving service, the drug information component that was provided by pharmacy staff written in a data sheet (check list) [9]. The population in this study were pharmacy staff who were in the pharmacy at the time of visit and gave the service. 121 pharmacies located in 3 districts in Tangerang City were visited. The minimum sample was calculated with the formula of Lwanga \& Lameshow. The number os sample in each district was calculated proportionally to the total population and then simple random sampling was chosen in taking the sample in that each district. Pharmacy staff referred to a person in charge in pharmacy who served the simulated patient at the time of visit. They can be pharmacist or non-pharmacist. Research permits were obtained from the Tangerang City Political and Nation Unity Office and the Tangerang City Health Office. Research recommendations were obtained from the IAI of Tangerang City. Ethical clearance was obtained from the Health Research Ethics Commission of the University of Indonesia with the number KET1227/UN2.F1/ETIK/PPM.00.02/2019. The inclusion criteria included: Pharmacy located in 3 sub-districts in the of Tangerang city; Pharmacies that were still operating when the research was conducted; Pharmacy with an official permit registered at the Health Office of the City of 
Tangerang. Meanwhile, the exclusion criteria were pharmacy staff who aware that they were being studied by a simulated patient. To obtain an overview of the services of pharmacy staff in providing drug information to patients with prescriptions obtained from doctors who was willing to cooperate in this study. In order to get an overview of antibiotics dispensing without a prescription, simulated patients asked different antibiotics from the prescription one for other family members just by showing the old empty strip. The quality of drug information service was calculated by the formula:

\section{The quality of information service $=$ The total score showed by pharmacy staff $\times 100 \%$ The maximum score}

The score was based on the drug information points list The data analysis used was univariate analysis.

\section{Result}

The result showed as seen in Figure 1 that the quality of drug information service in 3 districts, namely Cipondoh, Karawaci, and Tangerang districts was 33.70\%. The quality of drug information services provided by pharmacists in Cipondoh sub-district was 50\%, while for drug information services provided by non-pharmacist was $30.09 \%$. For Karawaci and Tangerang sub-districts, the quality of drug information services performed by non-pharmacist were $33.88 \%$ and $36.1 \%$ respectively and there were no pharmacists who provide drug information services to simulated patients, all drug information services are carried out by non-pharmacist.

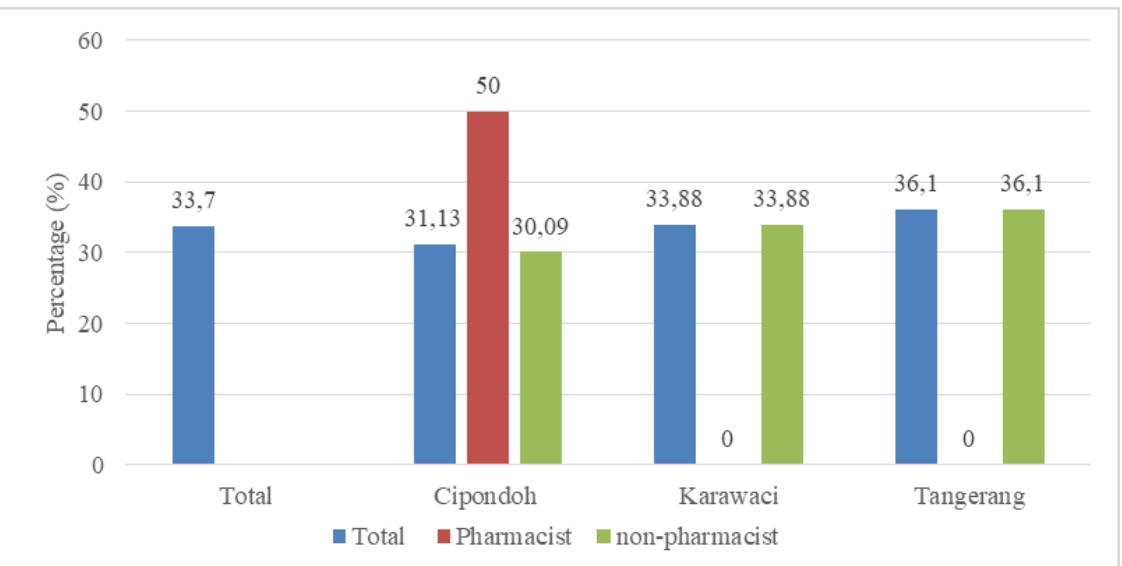

Fig.1. An overview of the quality of drug information services in cipondoh, Karawaci and Tangerang district pharmacies in the city of Tangerang, Cipondoh $(n=19)$, Karawaci $(n=15)$, Tangerang $(\mathrm{n}=21)$

Providing accurate, clear and up-to-date information to doctors, nurses, other health professionals and patients is a service that must be provided by pharmacists as described in the minister of health regulation number 73 of 2016 [1]. From the observations made in the study, the results are as in table 1 . It can be seen in table 1 that on average, the items of information provided on drug information services provided by pharmacy staff in three sub-districts in the 
city of Tangerang were as follows: indication (86.95\%), the time of use (morning / afternoon / afternoon / evening) of 3.34\%, Drug administration deal with food intake (before, during, after) of $52.15 \%$, frequency $(89.16 \%)$, Number of drug for taking in each time $(89.16 \%)$, and drug name $(85.36 \%)$. There were no pharmacy staff who provide drug information items related to drug interactions and ways to prevent them, drug side effects and ways to prevent / overcome them, foods and beverages to avoid, and storage methods.

Table 1. An overview of drug information services in Cipondoh, Karawaci, and Tangerang district pharmacies in the city of Tangerang $(n=55)$

\begin{tabular}{llllll}
\hline $\mathbf{N}$ & Drug information & $\begin{array}{l}\text { Cipondoh } \\
\mathbf{0}\end{array}$ & $\begin{array}{l}\text { Karawaci } \\
\mathbf{p o i n}\end{array}$ & $\begin{array}{l}\text { Tangerang } \\
(\mathbf{\%})\end{array}$ & $\begin{array}{l}\text { Avar } \\
\text { age }\end{array}$ \\
\hline 1 & indication & 78,94 & 86,67 & 95,23 & 86.95 \\
2 & Time of administration & 5,26 & 0 & 4,76 & 3.34 \\
3 & $\begin{array}{l}\text { Drug administration } \\
\text { deal with food intake }\end{array}$ & 52,63 & 46,67 & 57,14 & 52.15 \\
& frequency & 78,94 & 93,33 & 95,23 & 89.16 \\
5 & $\begin{array}{l}\text { Number of drug for } \\
\text { taking in each time }\end{array}$ & 78,94 & 93,33 & 95,23 & 89.16 \\
6 & Drug name & 78,94 & 86,67 & 90,47 & 85.36 \\
\hline
\end{tabular}

Figure 2 showed a pharmacy staff who provided drug information services to simulated patients. It can be seen that drug information services in the District of Cipondoh, Karawaci, Tangerang, the City of Tangerang was almost entirely carried out by non-pharmacist. Nonpharmacist mean the pharmacy staff who served the simulated patient except pharmacist. The researcher did not identify in more detail whether they were pharmacy technician or others. There was only one pharmacist who provided direct services to simulated patients, namely in the Cipondoh sub-district.

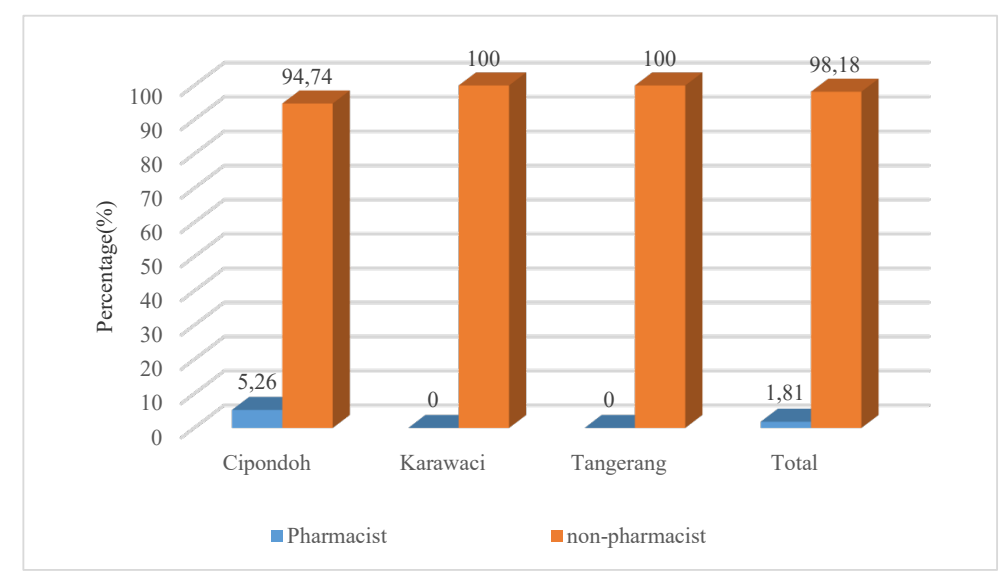

Fig. 2. Description of pharmacy staff providing drug information services

Figure 3 showed the pattern of antibiotics dispensing without a prescription in three subdistricts in Tangerang city. It can be seen that in Cipondoh sub-district there is 1 pharmacy $(5.26 \%)$ that did not sell antibiotics without using a doctor's prescription. In Karawaci sub- 
district, out of 15 pharmacies, there are 2 pharmacies $(13.33 \%)$ that did not serve simulated patient requests for antibiotics without using a doctor's prescription while in Tangerang subdistrict it is found that out of 21 pharmacies there were 3 pharmacies $(14.28 \%)$ that refused to give antibiotics without a doctor's prescription. Pharmacy staff that did not serve the sale of antibiotics without doctor's prescription was $10.91 \%$ out of 55 pharmacies. Two of them said they did not have the antibiotics that the simulated patient asked for while the other 4 pharmacies said they could not dispense the antibiotic without a doctor's prescription.

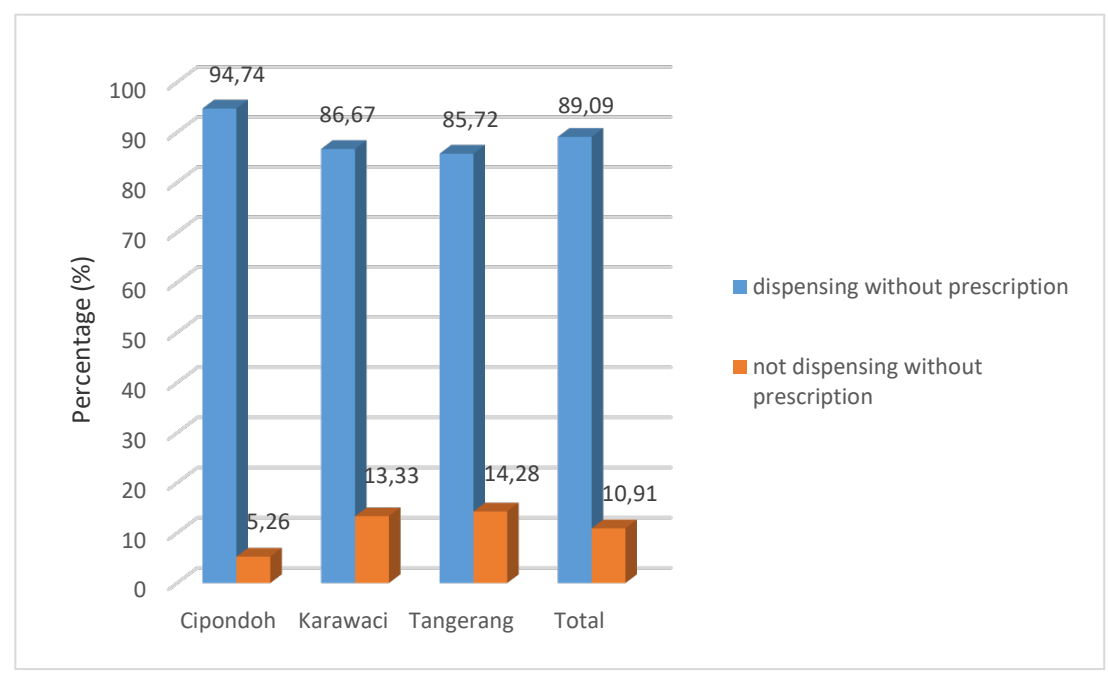

Fig. 3. An overview of antibiotics dispensing without prescription at a pharmacy in the city of Tangerang

\section{Discussion}

The quality of drug information services for prescriptions containing antibiotics in Tangerang City was still not in accordance with what is stated in the minister of health regulation number 73 of 2016. The other studies conducted in Tangerang Selatan city, Banten; Nganjuk district, East Java; and Bandung district, West Java reported the similar results. By providing drug information service, it is expected that patients will have good knowledge and understanding so that they realize how important it is for them to comply with the medication. Regarding the use of antibiotics, this adherence can minimize the occurrence of drug resistance. Regarding the use of antibiotics, it has also been stated in the regulation of the Minister of Health of the Republic of Indonesia number 2406 / MENKES / PER / XII / 2011 in respect to the provision of information and counseling, it states that pharmacists can provide drug information orally or in writing and counseling can be carried out by pharmacistswith the show and tell method, and can be accompanied by providing written information in the form of a leafet [10].

According to pharmaceutical service guidelines for antibiotic therapy, pharmacists have a role in educational activities. Pharmacists act as providers of education and information about controlling antibiotic resistance and infection prevention and control to health workers, patients and patient families. Educational activities that are accompanied by socialization of policies and procedures for antibiotic restriction can increase the effectiveness of education. The educational activities include: organizing seminars and workshops, publishing newsletters and educational 
forums [11]. Providing accurate, clear and up-to-date information to doctors, nurses, other health professionals and patients is a service that must be provided by pharmacists as described in the minister of health regulation number 73 of 2016 [1].

Pharmacists staff (especially pharmacist) should provide adequate information contain several items to patients [12]. This study find that there are still many items of drug information that have not been conveyed to patients even though the information is very important for them. For example patients should be informed about side effects that are more likely to occur in order to increase their awareness when these side effects occur. It will also reduce their anxiety when drug side effects occur to them. How to deal with drug side effects is also a very important item of drug information to convey. Likewise and other items of drug information that would be better conveyed to patients.

Most of non-pharmacists served the simulated patients. This finding is in line with research conducted at a pharmacy in the city of Bandar Lampung, which reported that $83.3 \%$ of drug information was provided by non-pharmacists, namely pharmacy technician [9]. Likewise with other research conducted in the Garut, West Java. This study reported that some pharmacy staffs who provided drug information services to patients were non-pharmacists [13]. The same condition happened at a pharmacy in South Tangerang city, Banten. Pharmacy is a place where pharmacists carry out pharmacy practices which are their professional responsibility. Pharmacists have the main task of providing pharmaceutical services to patients which means that pharmacists can provide direct and responsible services to patients in order to help patients get the best benefit from the treatment they are currently undergoing. Providing drug information in the form of educational and counseling activities is the application of direct and responsible services and is one of the cores of the implementation of professionalism [14]; [1]

$89.09 \%$ of pharmacy staff dispensed antibiotic without prescription to simulated patient. Several previous studies also showed the same results were in a study conducted in the City of Surabaya, $81.9 \%$ of 133 respondents received antibiotics without a doctor's prescription because they had used antibiotics before [15]. Research conducted in Nganjuk regency showed that from $94 \%$ of sampled pharmacy dispensed antibiotics without doctor's prescription [2]. The latest research conducted in Bandung Regency showed that dispensing of antibiotics without a doctor's prescription was $81.54 \%$ [3] .

Antibiotics are prescription only medicine (POM) where it must be purchased using a doctor's prescription[16]. Antibiotics are drugs most often used in infections caused by bacteria. The high intensity of antibiotic use and inappropriate drug use can lead to bacterial resistance. Where the lack of patient knowledge and the behavior of patients who stop taking antibiotics when they feel cured, non-compliance with the frequency of administration and non-compliance with the time of administration can lead to resistance [4,17]. The dispensing of antibiotics without a doctor's prescription occurs not only in developing countries, but also in developed countries. For example, in European countries such as Romania, and Lithuania, a high prevalence of self-medication with antibiotics is also foundand the use of antibiotics was highest for urinary tract infections 79.7\% [7]. A study in Saudi Arabia showed 77.6\% of antibiotics were administered without a doctor's prescription [8]. 


\section{Conclusion}

The quality of drug information service provided by pharmacy staff to patient with prescription contains antibiotic is low. Most pharmacies in Tangerang city within the visit period of simulated patient can dispense antibiotic on patient request without prescription. Evaluating the service quality and the dispensing pattern in several visits could be interesting in the next study.

\section{Reference}

[1] Kementerian Kesehatan RI. Peraturan Menteri Kesehatan Republik Indonesia Nomor 73 Tahun 2016 tentang Standar Pelayanan Kefarmasian di Apotek. (2016)

[2] Al Faaz, M.S.: Gambaran Pelayanan Informasi Obat Resep Antibiotik dan Pola Penjualan Non Resepnya di Apotek Wilayah Kabupaten Ngajuk. Universitas Islam Negeri Syarif Hidayatullah Jakarta. (2018)

[3] Hanif, F.D.: Gambaran Pelayanan Informasi Obat Jenis Antibiotik Resep dan non Resep di Apotek 3 Kecamatan Wilayah Kabupaten Bandung. Universitas Islam Negeri Syarif Hidayatullah Jakarta.(2019)

[4] WHO.: Worldwide country situation analysis : response to antimicrobial resistance. (2015)

[5] Ihsan, S. Akib, NI.: Studi Penggunaan Antibiotik Non Resep Di Apotek Komunitas Kota Kendari. Media Farm.13(2):272-84 (2016)

[6] Al-Azzam, S.I. Al-Husein, B.A. Alzoubi, F. Masadeh, M.M. Al-Horani, M.A.S.: Selfmedication with antibiotics in Jordanian population. Int J Occup Med Environ Health. 20(4):373-80 (2007)

[7] Llor, C. Cots, J.M.: The Sale of Antibiotics without Prescription in Pharmacies in Catalonia, Spain. Clin Infect Dis. 48(10):1345-9 (2009)

[8] Bin Abdulhak, A,A., Altannir, M.A., Almansor, M.A. Almohaya, M.S. Onazi, A.S. Marei, M.A, et al. : Non prescribed sale of antibiotics in Riyadh, Saudi Arabia: A cross sectional study. BMC Public Health. 11. (2011)

[9] Yulyuswarni : Propil Pelayanan Informasi Obat Terhadap Pasien dengan Resep Antibiotika di Apotek Kota Bandar Lampung', Jurnal Analis Kesehatan. 6(1), pp. 590594 (2017)

[10] Kementerian Kesehatan RI. Peraturan Menteri Kesehatan Republik Indonesia Nomor 2406/MENKES/PER/XII/2011 tentang Pedoman Umum Penggunaan Antibiotik. Pp 31$41(2011)$

[11] Kementerian Kesehatan RI. Pedoman Pelayanan Kefarmasian untuk Terapi Antibiotika Kementrian Kesehatan Republik Indonesia. 2011;

[12] American Society of Health-System Pharmacist 'ASHP guidelines on pharmacistconducted patient education and counseling', American Journal of Health-System Pharmacy. 54, pp. 431-434 (2011)

[13] Suci, R. P., Saibi, Y. Dasuki, A. : Kualitas Pelayanan Informasin Obat ( Konseling ) di Apotek Kabupaten Garut., Jurnal Pharmascience. 05(01), pp. 1-7 (2018)

[14] Ghaibi, S, Ipema, H. Gabay, M. : ASHP guidelines on the pharmacist's role in providing drug information. American Journal of Health-System Pharmacy. 72(7), pp. 573-577 (2015) 
[15] Wuwur, L.N.: Studi Penggunaan Antibiotik Tanpa Resep Dokter di Beberapa Apotek Kecamatan Rungkut Surabaya. J Ilm Mhs Farm Univ Surabaya. (2012)

[16] Direktorat Jenderal Pelayanan Kefarmasian dan Alat Kesehatan. Undang-Undang Obat Keras. (1949)

[17] Krisnanta, I. Parfati, N. Presley, B. Setiawan, E. : Analisis Profil dan Faktor Penyebab Ketidakpatuhan Pengasuh Terhadap Penggunaan Antibiotik pada Pasien Anak. Jmpf. 8(1):39-50 (2018) 